\title{
Prenatal diagnosis and molecular cytogenetic characterization of a de novo duplication of I5q24.3-q26. I
}

This article was published in the following Dove Press journal:

The Application of Clinical Genetics

\author{
Isabel Ochando 1,2 \\ Melanie Cristine Alonzo \\ Martínez ${ }^{3}$ \\ Ana María Serrano ${ }^{3}$ \\ Antonio Urbano' \\ Eduardo Cazorla ${ }^{3}$ \\ Dolores Calvo ${ }^{4}$ \\ Joaquín Rueda ${ }^{1,2}$ \\ 'Genetics Unit, Unidad de Genética, \\ Hospital Clínica Vistahermosa, \\ Alicante, Spain; ${ }^{2}$ Departamento de \\ Histología y Anatomía, Universidad \\ Miguel Hernández, Alicante, Spain; \\ ${ }^{3}$ Department of Obstetrics and \\ Gynecology, Servicio de Ginecología y \\ Obstetricia, Hospital Universitario de \\ Torrevieja, Alicante, Spain; ${ }^{4}$ Emergency \\ Laboratory, Laboratorio Urgencias, \\ Hospital Clínico Universitario, \\ Valladolid, Spain
}

Correspondence: Isabel Ochando Unidad de Genética, Hospital Clínica Vistahermosa, Avenida de Denia 103, 03015 Alicante, Spain

Tel +34965268000

Fax +34965262405

Email iochando@geneticavistahermosa.es

\begin{abstract}
Reported cases of distal 15q interstitial duplications are uncommon and do not result in a recognizable pattern of abnormalities. Some studies report prenatal overgrowth, while others describe growth retardation. We present molecular cytogenetic characterization of a $14 \mathrm{Mb}$ interstitial duplication, encompassing 81 Online Mendelian Inheritance in Man (OMIM) genes, in a fetus with single umbilical artery and short limbs. We propose that growth restriction, previously described and present in our patient, may be due to duplication of a gene or genes contained in the $15 \mathrm{q} 24$ region.
\end{abstract}

Keywords: distal $15 q$ trisomy, prenatal diagnosis, short limbs

\section{Introduction}

Reported cases of distal 15q duplications are very uncommon; in fact, there are $\sim 100$ cases reported, and even less de novo duplications as in this case report. Previous authors have described a distal $15 \mathrm{q}$ trisomy syndrome characterized by prenatal and postnatal overgrowth, developmental delay, craniofacial and skeletal malformations, and genital abnormalities, particularly in affected males. ${ }^{1}$ There are only few reported cases of de novo single duplication of $15 q 24$-qter region. ${ }^{2-7}$ The type and severity of reported anomalies depend on the length and location of the duplicated region of chromosome $15 \mathrm{q}$, but there is a common phenotype consisting of minor craniofacial anomalies (downslanting palpebral fissures and ptosis, large prominent nose, facial asymmetry, and micrognathia), arachnodactyly and camptodactyly, heart defects (septal communications, patent ductus arteriosus, pulmonary artery stenosis), hypogonadism and cryptorchidism, scoliosis, severe developmental delay, and anencephaly. ${ }^{3}$

Reported patients with trisomy of 15 q25/q26qter have presented prenatal and postnatal overgrowth. ${ }^{1,2,4-6}$ Overgrowth has been attributed to overexpression of the $I G F 1 R$ gene, which is located on $15 \mathrm{q} 26.3$. On the contrary, patients with trisomy of $15 q 24 q t e r$ region exhibit growth restriction/intrauterine growth restriction (IUGR) and developmental delay. ${ }^{2,7-10}$

In this report, we present a prenatal diagnosis of a fetus with single umbilical artery, short limbs, and a de novo duplication of $15 \mathrm{q} 24.3 \mathrm{q} 26.1$.

\section{Clinical report}

A 30-year-old patient had a routine anomaly scan at $21+1$ weeks gestation. Although her first trimester combined screening risk was low, the ultrasound scan showed a male fetus with short long bones ( -2.5 standard deviation [SD]), according to Chitty and 
Altman ${ }^{11}$ (femur length [FL]: 27-27 mm, tibia: 25-26 mm, fibula: $25-25 \mathrm{~mm}$, humerus: $25-26 \mathrm{~mm}$, ulna: $25-26 \mathrm{~mm}$, radius: $25-25 \mathrm{~mm}$ ) but with normal morphology and mineralization signs, corresponding to a $19+5$ gestation week fetus, with an estimated weight of $289 \mathrm{~g}$ (according to Hadlock tables, biparietal diameter [BPD] $45 \mathrm{~mm}$, head circumference [CC] $174 \mathrm{~mm}$, abdominal circumference [AC] $147 \mathrm{~mm}$ ) (Figure 1A and B). The remaining anatomy was normal except for a single umbilical artery (Figure 1C). At Week 24, the fetus still showed 2-week-younger measurements, and the transverse cerebellar diameter was $23 \mathrm{~mm}$, below the 5 th centile, according to Snijders and Nicolaides ${ }^{12}$ (Figure 1D). After ruling out an error in pregnancy dating, an amniocentesis was performed to find out the origin of the growth delay. The fetus karyotype showed a 15q duplication, visible by conventional G-banding (Figure 1E). The duplication was considered de novo because the parents displayed normal karyotypes on testing. Comparative genomic hybridization (CGH) array (KaryoNIM® Prenatal 60K; NIMGenetics, Madrid, Spain) was carried out to determine the size and extent of the duplication (Figure 1F). It was an interstitial duplication of $14 \mathrm{Mb}$ : 46,XY,dup(15)(q24.3q26.1).arr15q $24.3 \mathrm{q} 26.1(76223116-90340143) \times 3$. The duplicated region contains 257 genes in the Genes on Sequences National Center for Biotechnology Information (NCBI) map, of which 81 are in the Online Mendelian Inheritance in Man (OMIM) database. The patients underwent genetic counseling and opted for a termination of pregnancy. They declined postmortem examination.

Written informed consent has been provided by the patient to have the case details and any accompanying images published.
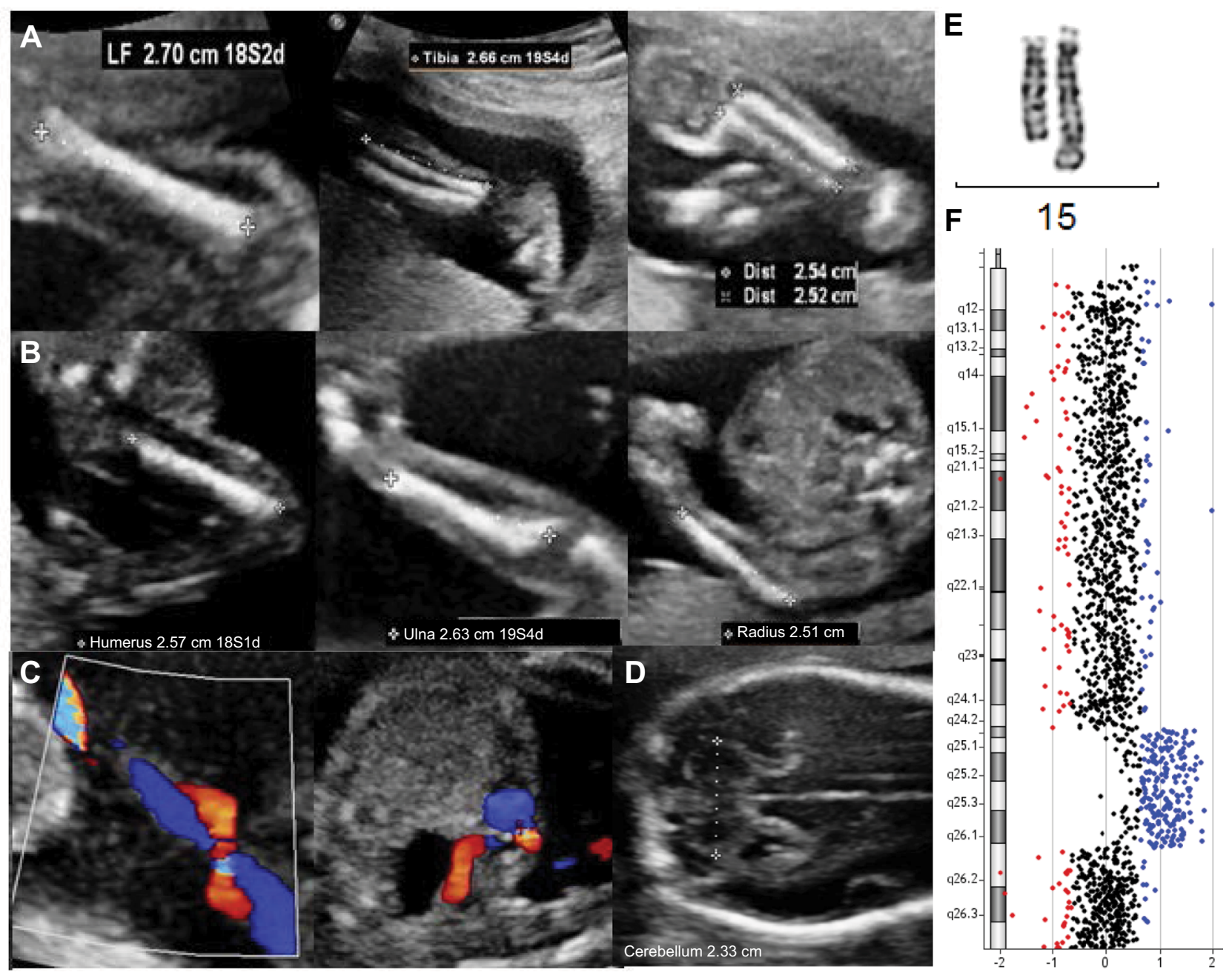

Figure I Morphologic ultrasonogram of a $21+1$-week male fetus with 19+5-week-ultrasound parameters.

Notes: Bone morphology and mineralization characteristics were normal. (A) From left to right: FL 27-27 mm, tibia 25-26 mm, and fibula 25-25 mm. (B) From left to right: humerus $25-26 \mathrm{~mm}$, ulna $25-26 \mathrm{~mm}$, and radius $25-26 \mathrm{~mm}$. (C) Single umbilical artery. (D) In Week 24 , the transverse cerebellar diameter was $23 \mathrm{~mm}$ (<p5). Next, characterization of the duplication was carried out by cytogenetic and molecular analyses. (E) Conventional G-banding of chromosome I5. The duplicated chromosome is on the right. (F) CGH array. Reduced dosage for probes is shown to the left (red) of the control two-copy line and increased dosage is shown to the right (blue). Abbreviation: $\mathrm{CGH}$, comparative genomic hybridization. 


\section{Discussion}

The fetus described in this report exhibited single umbilical artery, had short limbs, and had a de novo duplication of $15 \mathrm{q} 24.3 \mathrm{q} 26.1$. Based on the cases reported to date, it is not clear whether the duplication of 15q24-qter results in a recognizable pattern of abnormalities.

Zollino et al ${ }^{1}$ reported a total of 32 patients with $15 \mathrm{q}$ duplications and divided them in two groups: one group had trisomy for 15q21-24qter, showing microcephaly and normal prenatal growth; and the other group showed trisomy 15q25-26qter, characterized by prenatal overgrowth, macrocephaly, and craniosynostosis. The cause of overgrowth has been thought to be related to a dosage excess of the IGFIR gene, located in $15 \mathrm{q} 26.3$. $^{1,2,4-6}$ This gene is not contained in the region duplicated in the fetus we report herein.

Roggenbuck et $\mathrm{al}^{7}$ reported two unrelated cases with single 15q24q26.3 duplication showing small size. O'Connor et $\mathrm{al}^{6}$ reported a patient with a single $15 \mathrm{q} 24 \mathrm{qter}$ trisomy and normal sizes/measures at birth. Genesio et $a l^{8}$ described the case of a multiple-malformed newborn with IUGR and a de novo inverted duplication of $15 \mathrm{q} 21 \mathrm{q} 26.3$, with three copies of the IGFIR gene. The authors hypothesized that the IUGR depends on global transcription dysregulation more than the impairment of a single gene specifically correlated to the malformation. ${ }^{8}$ El-Hattab et a ${ }^{13}$ reported a case with short stature and developmental delay and a 15q24 microduplication that contained the OMIM genes SCAPER, ISL2, EFTA, NRG4, $F B X O 22$, and UBE2Q2. All these genes, except UBE2Q2, are duplicated in the fetus reported here. It is tempting to speculate that dosage excess of genes located in 15q24 leads to short limbs/IUGR instead of tall stature.

In the case of a fetal ultrasonogram displaying short long bones ( $<5$ th percentile), it is advisable to analyze their morphology and mineralization, as well as rule out a possible error in gestational dating and femur-humerus confusions. Then, differential diagnoses should include constitutional short stature, IUGR, skeletal dysplasia such as achondroplasia, and chromosomal abnormalities such as deletion of $15 \mathrm{q} 24$, similar to this case report.

This study underscores the utility of the CGH array in the characterization of the size and nature of rearrangements, as well as in predicting the severity of phenotypes, which depends on the length and location of the duplicated region. Associations between phenotypes and copy number variations of small chromosome regions provide valuable information about clinically important genes or regulatory elements and allow the investigation of their role in the phenotypes. Systematic characterization of newly reported patients provides useful information for clinicians and patients.

\section{Acknowledgments}

The authors wish to thank Miss Jéssica Calvo for technical support. This work was supported by Citolab and Cátedra de Biomedicina Reproductiva Vistahermosa. The abstract of this work was presented at the 10th European Cytogenetics Conference, Strasbourg, France, July 2015.

\section{Disclosure}

The authors report no conflicts of interest in this work.

\section{References}

1. Zollino M, Tiziano F, Di Stefano C, Neri G. Partial duplication of the long arm of chromosome 15: confirmation of a causative role in craniosynostosis and definition of a 15q25-qter trisomy syndrome. Am J Med Genet. 1999;87(5):391-394.

2. Cannarella R, Mattina T, Condorelli RA, et al. Chromosome 15 structural abnormalities: effect on $I G F 1 R$ gene expression and function. Endocr Connect. 2017;6(7):528-539.

3. Chen CP, Chen CY, Chern SR, et al. Molecular cytogenetic characterization of a duplication of 15q24.2-q26.2 associated with anencephaly and neural tube defect. Taiwan J Obstet Gynecol. 2017;56(4):550-553.

4. Gutiérrez-Franco Mde L, Madariaga-Campos Mde L, VásquezVelásquez AI, Matute E, Guevara-Yáñez R, Rivera H. A girl with 15q overgrowth syndrome and $\operatorname{dup}(15)(\mathrm{q} 24 \mathrm{q} 26.3)$ that included telomeric sequences. Korean J Lab Med. 2010;30(3):318-324.

5. Kim EY, Kim YK, Kim MK, et al. A case of de novo duplication of 15q24-q26.3. Korean J Pediatr. 2011;54(6):267-271.

6. O’Connor R, Al-Murrani A, Aftimos S, et al. Pure duplication of the distal long arm of chromosome 15 with ebstein anomaly and clavicular anomaly. Case Rep Genet. 2011;2011:5.

7. Roggenbuck JA, Mendelsohn NJ, Tenenholz B, Ladda RL, Fink JM. Duplication of the distal long arm of chromosome 15: report of three new patients and review of the literature. Am J Med Genet. 2004;126A(4):398-402.

8. Genesio R, De Brasi D, Conti A, et al. Inverted duplication of $15 \mathrm{q}$ with terminal deletion in a multiple malformed newborn with intrauterine growth failure and lethal phenotype. Am J Med Genet A 2004;128A(4):422-428.

9. Miller MS, Rao PN, Dudovitz RN, Falk RE. Ebstein anomaly and duplication of the distal arm of chromosome 15: report of two patients. Am J Med Genet. 2005;139A(2):141-145.

10. Roetzer KM, Schwarzbraun T, Obenauf AC, Hauser E, Speicher MR. Further evidence for the pathogenicity of 15q24 microduplications distal to the minimal critical regions. Am J Med Genet A. 2010;152A(12):3173-3178.

11. Chitty LS, Altman DG. Charts of fetal size: limb bones. BJOG. 2002;109(8):919-929.

12. Snijders RJ, Nicolaides KH. Fetal biometry at 14-40 weeks' gestation. Ultrasound Obstet Gynecol. 1994;4:34-48.

13. El-Hattab AW, Smolarek TA, Walker ME, et al. Redefined genomic architecture in 15q24 directed by patient deletion/duplication breakpoin mapping. Hum Genet. 2009;126(4):589-602. 


\section{Publish your work in this journal}

The Application of Clinical Genetics is an international, peer-reviewed open access journal that welcomes laboratory and clinical findings in the field of human genetics. Specific topics include: Population genetics; Functional genetics; Natural history of genetic disease; Management of genetic disease; Mechanisms of genetic disease; Counselling and ethical issues; Animal models; Pharmacogenetics; Prenatal diagnosis; Dysmorphology. The manuscript management system is completely online and includes a very quick and fair peer-review system, which is all easy to use. Visit http://www.dovepress.com/testimonials.php to read real quotes from published authors.

Submit your manuscript here: https://www.dovepress.com/the-application-of-clinical-genetics-journal 